\title{
Pengaruh Perilaku Ibu Terhadap Status Kesehatan Anak Baduta di Provinsi Jawa Tengah
}

\author{
Lilis Heri Mis Cicih \\ Program S3 IKM Fakultas Kesehatan Masyarakat Universitas Indonesia
}

\begin{abstract}
Latar belakang. Kesehatan merupakan hak dasar anak yang harus dipenuhi. Anak yang sehat menjadi investasi bagi modal manusia. Masa baduta adalah masa yang penting, karena merupakan masa kritis dalam kesehatan dan masa emas dalam pertumbuhan otak. Salah satu faktor berpengaruh terhadap status kesehatan baduta adalah perilaku ibu.

Tujuan. Mengetahui pengaruh perilaku ibu terhadap status kesehatan baduta (bawah dua tahun) di Provinsi Jawa Tengah. Provinsi yang memiliki jumlah penduduk banyak dan masih menghadapi berbagai permasalahan kesehatan balita.

Metode. Data yang digunakan adalah Susenas tahun 2007, dengan unit analisis baduta yang tinggal bersama ibunya. Metode analisis meliputi analisis deskriptif, odds ratio (OR), regresi logistik multinomial, dengan melakukan pengujian statistik Chi-square. Status kesehatan dicerminkan oleh keluhan kesehatan, sementara perilaku ibu dilihat dari status pemberian ASI eksklusif dan imunisasi dasar lengkap.

Hasil. Baduta yang mengalami keluhan kesehatan 42,47\%. Dilihat dari status pemberian ASI eksklusif, baduta yang pernah mendapatkan ASI lebih sehat daripada yang tidak pernah mendapatkan ASI. Sementara untuk baduta yang berstatus imunisasi tidak lengkap lebih rendah status kesehatannya dibandingkan baduta yang status imunisasinya lengkap atau belum lengkap.

Kesimpulan. Secara bersama-sama, status pemberian ASI dan kelengkapan imunisasi baduta berpengaruh signifikan terhadap status kesehatan baduta. Sari Pediatri 2011;13(1):41-8.
\end{abstract}

Kata kunci: status kesehatan, baduta, imunisasi, air susu ibu, keluhan kesehatan

\author{
Alamat korespondensi: \\ Lilis Heri Mis Cicih \\ Mahasiswa S3 IKM Fakultas Kesehatan Masyarakat Universitas Indonesia \\ E-mail:mcicih@yahoo.com
}

$\mathrm{P}$ eningkatan kesehatan merupakan suatu keharusan apabila bangsa Indonesia ingin mencapai pembangunan manusia yang tinggi. Kesehatan merupakan hak asasi manusia termasuk hak dasar anak yang harus dipenuhi dengan baik. Anak yang sehat akan menjadi investasi bagi modal manusia yang berkualitas di masa depan. Berbagai indikator kesehatan di Indonesia 
menunjukkan capaian kesehatan anak yang masih rendah. Angka kematian bayi (infant mortality ratel $I M R)$ mengalami sedikit penurunan dari 35 per 1.000 kelahiran hidup (Survey Demografi Kesehatan Indonesia atau SDKI 2002-2003) menjadi 34 per 1.000 kelahiran hidup (SDKI 2007). ${ }^{6}$ Pencapaian IMR masih jauh dari target yang ditetapkan oleh RPJMN 2010-2014 yaitu 26 per 1.000 kelahiran hidup. Begitu pula jika dibandingkan dengan target Pembangunan Milenium atau Millenium Development Goals (MDG's) yaitu 23 per 1.000 kelahiran hidup. Angka kematian anak bawah lima tahun (balita) mengalami penurunan dari 97 (SDKI 1991) menjadi 44 per 1.000 kelahiran hidup (SDKI). Meskipun demikian masih perlu upaya untuk menurunkan angka kematian balita, sehingga dapat mencapai target sebesar 32 per 1.000 kelahiran hidup pada tahun 2015 .

Indikator status gizi menunjukkan penurunan yang signifikan khususnya setelah ada hasil Riset Kesehatan Dasar (Riskesdas) tahun 2007. Sebelumnya, hasil Survey Sosial Ekonomi Nasional (Susenas 2005) menunjukkan persentase balita yang menderita gizi buruk 8,80\%. Hasil Susenas 2005 juga menunjukkan balita gizi kurang sebesar 19,24\%; gizi normal 68,48\%; dan gizi lebih 3,48\%. Pada Riskesdas 2007 terjadi penurunan yang cukup signifikan angka kekurangan gizi pada balita yaitu $18,4 \%$, terdiri dari gizi buruk 5,4\% dan gizi kurang 13\%. Sementara balita stunting (pendek) mencapai 36,8\%, balita wasting (kurus) 4,3\% dan gizi lebih 4,3\%. Hasil Riskesdas tahun 2010, memperlihatkan prevalensi balita kurang gizi (berat badan kurang) 18,0\%, di antaranya 4,9\% dengan gizi buruk. Pencapaian tersebut telah berada di bawah target MDG's tahun 2015, 18,5\%. Meskipun secara angka sudah tercapai target, namun status gizi anak balita masih perlu diperhatikan mengingat masih ditemukan kasus anak gizi buruk atau kurang. Dari segi cakupan imunisasi, hasil Riskesdas 2010 menunjukkan cakupan imunisasi campak pada anak umur 12-23 bulan $(74,5 \%) .{ }^{9}$ Cakupan imunisasi ini menurun dibandingkan cakupan tahun 2007 (81,6\%).

Berdasarkan hasil capaian indikator kesehatan tersebut, berbagai upaya masih perlu dilaksanakan untuk meningkatkan status kesehatan anak. Faktor yang berpengaruh terhadap status kesehatan anak dapat bersifat endogen maupun eksogen. Faktor eksogen menyangkut antara lain perilaku, lingkungan, sosial, budaya, ekonomi, dan geografi perlu ditangani dengan lebih efektif dan efisien. Sehubungan dengan itu, perlu melihat pengaruh faktor eksogen terhadap status kesehatan anak, khususnya anak baduta yang merupakan masa emas (Nadesul, 2005). Masa ini terkait dengan masa dengan kesempatan untuk memperoleh otak yang cerdas yang menghasilkan intelligence quotient (IQ) optimal, mencapai 80 persen (Rustihauser, 2003).22 Apabila anak baduta (bawah dua tahun) mempunyai status kesehatan yang buruk dapat berisiko terhadap kerusakan otak permanen atau tidak dapat dipulihkan kembali atau irreversible (Untoro, 2004).

Salah satu faktor eksogen yang penting terhadap status kesehatan baduta adalah perilaku ibu, sebagai orang yang berperan dalam pengasuhan baduta. Sehubungan dengan itu, penelitian ini ditujukan untuk mengetahui pengaruh perilaku ibu terhadap status kesehatan baduta. Moallemi $\mathrm{dkk}^{18,19}$ (2007) memperlihatkan adanya hubungan antara perilaku ibu dengan status kesehatan anak, khususnya kesehatan gigi. Begitu juga Mbagaya $\mathrm{dkk}^{16}$ (2005) mengemukakan bahwa status kesehatan anak sangat dipengaruhi oleh perilaku kesehatan ibu.

Analisis dibatasi hanya untuk Provinsi Jawa Tengah, salah satu provinsi dengan jumlah penduduk ketiga terbanyak se-Indonesia yaitu 32,18 juta jiwa (sekitar $14 \%$ dari penduduk Indonesia). Jumlah baduta 2,59\% dari total penduduknya (hasil Survei Penduduk Antar Sensus/SUPAS 2005). Sementara kondisi kesehatannya masih memerlukan perhatian.

Estimasi IMR pada tahun 2005 turun menjadi sekitar setengah dari tahun 2000. Pada laki-laki IMR menurun dari 50 menjadi 28, sedangkan pada perempuan turun dari 39 menjadi 20. Namun untuk status gizi, balita gizi buruk $(\mathrm{BB} / \mathrm{TB})$ dengan tanda klinis meningkat dari 1.652 kasus pada tahun 2006 menjadi 1940 kasus pada tahun 2007 (Dinas Provinsi Jawa Tengah, 2008).

\section{Metode}

Penelitian menggunakan data Susenas 2007 yang tersedia pada saat penelitian dilakukan. Data ini tersedia setiap tahun, mencakup berbagai informasi kesehatan secara umum, kondisi demografi, sosial ekonomi, perumahan, konsumsi, pengeluaran dan lingkungan.

Data untuk Provinsi Jawa Tengah. Jumlah sampel 1.578 blok sensus atau 25.248 rumah tangga, dengan baduta 2.956 jiwa. Dari jumlah tersebut yang memenuhi persyaratan untuk dianalisis lebih lanjut 2.854 baduta. Sebanyak 102 baduta tidak dimasukkan 
dalam analisis ini, karena baduta tersebut tidak tinggal bersama ibunya atau baduta tersebut tidak diketahui keterangan ibunya. Baduta laki-laki 52,98\%, dan baduta perempuan $47,02 \%$, umur kurang dari enam bulan $25,37 \%$ dan $74,63 \%$ umur 6-23 bulan.

Unit analisis adalah anak bawah dua tahun. Variabel umur baduta dibagi dua yaitu kurang 6 bulan dan 6-23 bulan. Variabel terikat yaitu status kesehatan baduta, yang dicerminkan oleh keluhan kesehatan selama sebulan sebelum survei. Variabel terikat dibagi menjadi 1. Ada keluhan dan gangguan aktivitas sehari-hari, 2. Ada keluhan, dan 3. Tidak ada keluhan dan gangguan. Hanya sayang dalam data Susenas tidak dirinci aktivitas yang dilakukan oleh baduta. Varibel bebas meliputi perilaku ibu, karakteristik rumah tangga, karakteristik baduta, dan sanitasi lingkungan. Khusus untuk perilaku ibu, dilihat dari pemberian ASI eksklusif dan imunisasi baduta. Imunisasi terdiri dari tiga kategori yaitu imunisasi belum lengkap, imunisasi tidak lengkap, dan imunisasi sudah lengkap. Pemberian ASI eksklusif, dibedakan menjadi pernah di beri ASI, dan tidak pernah diberi ASI. Metode analisis disajikan secara deskriptif dan inferensial dengan menggunakan model regresi multinomial logistik dan $N$-Way tabulation. Selain itu dilakukan analisis deskriptif odds ratio, analisis inferensial yang dilakukan analisis multivariat dengan menggunakan model regresi logistik.

Pengolahan data dilakukan melalui tahap editing; coding; cleaning; scoring; dan gabung. Selanjutnya data disesuaikan dengan tujuan penelitian dengan cara mengurutkan data, memberikan koding, dan mengelompokan data sesuai dengan tujuan penelitian. Membuat variabel komponen dengan mencoba berbagai metode, misalkan dengan membuat perpotongan data yang sesuai dengan mengikut sertakan sensitifitas dan spesifisitas.

\section{Keterbatasan penelitian}

Rancangan Susenas adalah cross sectional, suatu rancangan penelitian dengan pengukuran, dan pengamatan terhadap variabel yang dilakukan pada waktu yang sama. Mengingat rancangan Susenas berbeda dengan rancangan penelitian yang kami buat, maka variabelvariabel terbatas pada data yang tersedia. Data cross sectional tidak dapat menjelaskan secara tepat besarnya hubungan variabel bebas dengan variabel terikat, serta tidak dilakukan kontrol terhadap variabel yang diduga berpengaruh terhadap status kesehatan baduta.

\section{Hasil}

\section{Keluhan kesehatan baduta}

Di antara 2.854 jiwa baduta, $1.212(42,46 \%)$ mengeluh sakit. Didapatkan 13,03\% baduta mengeluh sakit namun tidak sampai menganggu, namun 29,43\% mengalami keluhan kesehatan sampai teganggu aktivitasnya sehari-hari. Duapuluh lima persen diantara 1.212 baduta mengalami satu keluhan kesehatan selama sebulan sebelum penelitian. Paling banyak baduta mengalami tiga keluhan kesehatan $(38,20 \%)$, sementara baduta yang mengalami enam keluhan kesehatan $0,08 \%$.

Jenis keluhan terbanyak yang dialami baduta adalah pilek, $(73,93 \%)$, batuk $(65,76 \%)$, demam $(65,10 \%)$, sedangkan diare $14,19 \%$. Keluhan yang sedikit dialami baduta yaitu sesak/napas, nyeri kepala berulang dan nyeri gigi, masing-masing tidak mencapai 5\%. Sementara keluhan lainnya mencapai 11,63\%, namun tidak ada keterangan jenis keluhannya.

Tabel 1 menyajikan jumlah dan persentase baduta yang mengalami keluhan kesehatan serta urutan ranking menurut Kabupaten/Kota. Enam kabupaten/ kota, lebih dari $50 \%$ anak baduta mengalami keluhan kesehatan, yaitu Kendal, Purworejo, Banyumas, Grobogan, Kota Pekalongan, Brebes, sedangkan Wonogiri merupakan kabupaten dengan keluhan kesehatan terendah $(21,31 \%)$.

\section{Perilaku ibu}

Sebanyak 95,20\% baduta yang pernah mendapatkan ASI. Baduta yang diimunisasi tidak lengkap, $(4,8 \%)$ dan lengkap $(32,94 \%)$. Selanjutnya disajikan pada Tabel 1, jumlah, persentase dan odd ratio status kesehatan baduta dilihat dari status pemberian ASI dan kelengkapan imunisasi.

\section{Pemberian ASI}

Baduta yang tidak pernah diberi ASI lebih banyak mengalami keluhan kesehatan sampai terganggunya aktivitas sehari-hari $(32,85 \%)$ dibanding yang diberi ASI (29,26\%). Baduta yang tidak pernah mendapat ASI, risiko mengalami keluhan kesehatan 1,60 kali, peluang tidak mengalami keluhan kesehatan. Sementara risiko baduta tidak pernah diberi ASI 
mengalami keluhan kesehatan sampai terganggu aktivitas sehari-hari 1,31 kali peluang tidak mengalami keluhan kesehatan. Hasil uji Chi-square menunjukkan pemberian ASI berpengaruh signifikan terhadap status kesehatan baduta.

\section{Kelengkapan imunisasi}

Baduta mengalami keluhan kesehatan sampai terganggunya aktivitas sehari-hari lebih banyak pada baduta yang status imunisasi tidak lengkap $(33,92 \%)$ dibanding baduta dengan status imunisasi belum lengkap $(27,6 \%)$ dan lengkap 32,02\%. Umumnya baduta dengan imunisasi belum lengkap mayoritas berumur kurang dari 9 bulan, dan banyak yang masih diberi ASI selain makanan pendamping ASI.

Risiko baduta untuk mengalami keluhan kesehatan pada baduta dengan status imunisasi tidak lengkap lebih tinggi dibanding baduta dengan status imunisasi belum lengkap dan lengkap. Pada baduta dengan status imunisasi tidak lengkap, risiko keluhan kesehatan tanpa terganggu aktivitas sehari-hari 1,35 kali peluang tidak mengalami keluhan kesehatan. Sementara risiko keluhan kesehatan sampai terganggu aktivitas seharihari: 1,18 kali peluang tidak mengalami keluhan kesehatan.

Hasil uji Chi-square=29,454 dan nilai $\mathrm{p}=0,000$, artinya status kelengkapan imunisasi berpengaruh signifikan terhadap status kesehatan baduta. Temuan ini sesuai dengan temuan Sumargono (1989) yang menunjukkan balita yang tidak diimunisasi secara lengkap mempunyai risiko yang lebih besar untuk menderita ISPA/pnemonia dibandingkan dengan balita yang mendapatkan imunisasi lengkap.

\section{Perilaku ibu terhadap status kesehatan baduta}

Berdasar hasil inferensial diperoleh Chi-square= 40,008 , dengan $\mathrm{df}=10$, dan $\mathrm{p}=0,000$, artinya secara bersama-sama antara status pemberian ASI dan status imunisasi baduta berpengaruh signifikan terhadap status kesehatan baduta. Status pemberian ASI, dan status kelengkapan imunisasi merupakan faktor-faktor yang menentukan status kesehatan baduta. Hasil regresi logistik menunjukkan variabel interaksi baduta yang pernah diberi ASI, serta yang berstatus imunisasi belum lengkap yang signifikan. Dengan demikian hanya baduta yang pernah diberi ASI dan status imunisasi belum lengkap yang berpengaruh signifikan terhadap status kesehatan baduta. Baduta yang pernah diberi ASI dan status imunisasinya belum lengkap, risiko mengalami keluhan kesehatan dan terganggu kegiatan sehari-harinya lebih rendah 0,71 kali baduta yang pernah diberi ASI dan berstatus imunisasi lengkap. Sedangkan baduta yang pernah diberi ASI dan status imunisasinya belum lengkap, risiko mengalami keluhan kesehatan, tapi tidak terganggu kegiatan sehari-harinya lebih rendah 0,60 kali baduta yang pernah diberi ASI dan status imunisasinya lengkap.

Tabel 1. Jumlah, persentase, dan Odds ratio status kesehatan baduta

\begin{tabular}{|c|c|c|c|c|c|c|c|c|c|c|}
\hline \multirow[b]{2}{*}{ Variabel } & \multirow[b]{2}{*}{ Kategori } & & \multicolumn{3}{|c|}{ Status Kesehatan Baduta } & \multirow[b]{2}{*}{ Jumlah } & \multicolumn{2}{|c|}{ Odds Ratio } & \multirow[b]{2}{*}{$\chi^{2}$} & \multirow[b]{2}{*}{ p-value } \\
\hline & & & $\begin{array}{l}\text { Keluh dan } \\
\text { terganggu }\end{array}$ & keluh & sehat & & $\begin{array}{c}\text { Keluh \& } \\
\text { terganggu }\end{array}$ & keluh & & \\
\hline \multirow{4}{*}{$\begin{array}{l}\text { Status } \\
\text { pemberian } \\
\left.\text { ASI }{ }^{*}\right)\end{array}$} & Tidak & $\mathrm{n}$ & 45 & 24 & 68 & 137 & 1,31 & 1,60 & \multirow{4}{*}{4,350} & \multirow{3}{*}{0,114} \\
\hline & \multirow{3}{*}{ Pernah } & $\%$ & 32,85 & 17,52 & 49,64 & 100 & & & & \\
\hline & & $\mathrm{n}$ & 795 & 348 & 1.574 & 2.717 & 1,00 & 1,00 & & \\
\hline & & $\%$ & 29,26 & 12,81 & 57,93 & 100 & & & & \multirow{7}{*}{0,000} \\
\hline \multirow{6}{*}{$\begin{array}{l}\text { Status } \\
\text { kelengkapan } \\
\text { imunisasi } \\
\left.{ }_{* *}\right)\end{array}$} & \multirow[t]{2}{*}{ Belum lengkap } & $\mathrm{n}$ & 481 & 195 & 1.067 & 1.743 & 0,74 & 0,62 & \multirow{6}{*}{29,454} & \\
\hline & & $\%$ & 27,6 & 11,19 & 61,22 & 100 & & & & \\
\hline & Tidak lengkap & $\mathrm{n}$ & 58 & 32 & 81 & 171 & 1,18 & 1,35 & & \\
\hline & \multirow{3}{*}{ Lengkap } & $\%$ & 33,92 & 18,71 & 47,37 & 100 & \multirow{3}{*}{1,00} & \multirow{3}{*}{1,00} & & \\
\hline & & $\mathrm{n}$ & 301 & 145 & 494 & 940 & & & & \\
\hline & & $\%$ & 32,02 & 15,43 & 52,55 & 100 & & & & \\
\hline
\end{tabular}

Keterangan :

*) signifikan pada $\alpha=20 \%$

**) signifikan pada $\alpha=5 \%$ 


\section{Pembahasan}

Berdasarkan hasil penelitian, baduta yang pernah mendapatkan ASI mempunyai status kesehatan yang lebih baik daripada yang tidak pernah mendapatkan ASI. Sementara untuk baduta berimunisasi tidak lengkap status kesehatannya paling rendah dibandingkan yang status imunisasinya lengkap atau belum lengkap. Dengan demikian status pemberian ASI dan status imunisasi merupakan faktor yang menentukan status kesehatan baduta. Pemberian ASI eksklusif dan imunisasi dasar bagi baduta dapat berperan dalam menurunkan angka kematian bayi. Beberapa hasil penelitian memperlihatkan bahwa kematian bayi penderita diare banyak terjadi bayi yang tidak diberi ASI. Apalagi kalau dilihat dari hasil Riskesdas 2007, diare merupakan penyebab utama kematian bayi.

Bagi baduta terutama yang berumur kurang dari enam bulan, ASI merupakan makanan terbaik karena mengandung semua nutrisi essensial untuk pertumbuhan, dan antibodi yang melindungi kesehatan anak. Temuan Seda (2008) menunjukkan bayi yang menderita diare, pnemonia, infeksi setelah kelahiran meninggal akibat tidak diberi ASI. Temuan ini diperkuat oleh Depkes (2004) dan UNICEF (2005) bahwa ASI dianjurkan sebagai makanan utama, dan tunggal yang dibutuhkan oleh bayi berumur 0-6 bulan. Hal ini terkait dengan ASI yang mengandung zat gizi, dan cairan yang diperlukan untuk proses pertumbuhan dan perkembangan anak secara wajar dan sehat.

Mengingat pentingnya pemberian ASI dan imunisasi dasar, maka perlu upaya untuk meningkatkan kesadaran ibu untuk mempunyai perilaku kesehatan yang baik terhadap baduta. Khususnya untuk Provinsi Jawa Tengah perlu mengimplementasikan dengan baik misi pembangunan kesehatan yang diemban.

Peningkatan status kesehatan baduta perlu diupayakan melalui peningkatan pelayanan kesehatan yang bermutu, merata, dan terjangkau bagi seluruh masyarakat yang tercermin dengan terwujudnya antara lain,

1. Pembangunan berwawasan kesehatan, kualitas lingkungan, perilaku hidup sehat serta kemandirian individu, keluarga dan masyarakat di bidang kesehatan.

2. Kesehatan individu, keluarga dan masyarakat melalui peningkatan pemerataan, pemanfaatan, serta peningkatan kualitas pelayanan kesehatan masyarakat, dan perorangan yang berkesinambungan.
Terkait dengan penelitian ini, upaya peningkatan kesehatan dilakukan dengan cara mengubah perilaku laku ke arah perilaku kesehatan yang baik, yang berpengaruh terhadap status kesehatan baduta. Apalagi kalau dilihat capaian imunisasi dasar lengkap yang masih jauh dari target 46,2\% (Riskesdas 2007), sementara target Indonesia Sehat 2010 yaitu 100\% pada tahun 2010.

Dalam rangka meningkatkan status kesehatan anak, pemerintah dan berbagai pihak yang peduli telah mengupayakan berbagai langkah untuk meningkatkan akses masyarakat terhadap layanan kesehatan yang berkualitas serta mempromosikan perilaku hidup bersih dan sehat (PHBS) di rumah tangga. Perilaku tersebut meliputi pemberian ASI eksklusif (pemberian ASI saja sampai bayi berumur 6 bulan). Perilaku dianggap merupakan faktor amat penting yang mempengaruhi kesehatan, termasuk perilaku ibu terhadap kesehatan anak baduta.

Implementasi di daerah khususnya Provinsi Jawa Tengah, perlu ada keseriusan dan kesadaran dari Dinas Kesehatan yang didukung oleh pemerintah daerah dalam melaksanakan pembangunan kesehatan, khususnya peningkatan kesehatan baduta. Peningkatan kesehatan baduta merupakan suatu investasi modal manusia masa depan, yang sangat diperlukan untuk pembangunan bangsa. Usia 0-2 tahun dalam kehidupan anak merupakan jendela kesempatan sekaligus masa kritis karena sebagian besar perkembangan otak dan syaraf terjadi dalam periode tumbuh kembang tersebut.

Dalam rangka itu, perlu meningkatkan peran kelembagaan di masyarakat, seperti posyandu, terutama ditujukan untuk menjangkau akses masyarakat kurang mampu atau miskin. Umumnya program kesehatan dirancang dengan bagus di tingkat pusat, namun dalam implementasinya belum tentu menyentuh seluruh masyarakat. Khususnya masyarakat miskin, terpencil, dan tinggal di darah tertinggal atau terpencil. Sebagai contoh promosi perilaku hidup sehat, masih perlu diperluas jangkauannya untuk masyarakat yang kurang akses. Semua pihak harus mempunyai kesadaran bahwa kesehatan adalah hak semua orang dan semua orang mempunyai akses yang sama terhadap kesehatan. Seharusnya tidak ada alasan bagi pemerintah daerah untuk tidak memberikan prioritas bagi peningkatan kesehatan masyarakat.

Kelembagaan semacam posyandu ditujukan sebagai sarana untuk pendidikan gizi, rehabilitasi gizi buruk, serta promosi PHBS bagi baduta serta pos gizi. 
Selain itu dapat berperan sebagai pusat pemeriksaan serta perawatan kehamilan rutin, peningkatan keterampilan ibu dalam memberikan ASI Eksklusif, dan pemberian makanan bagi ibu hamil.

\section{Kesimpulan}

Hasil analisis data Susenas 2007 memperlihatkan bahwa perilaku ibu hasil mempunyai pengaruh yang signifikan dengan status kesehatan baduta. Di Provinsi Jawa Tengah, baduta yang mengalami keluhan kesehatan $42,5 \%$ dari 2.854 baduta. Rata-rata mengalami sebanyak tiga keluhan, dengan keluhan terbanyak adalah pilek, batuk, dan panas. Beberapa kabupaten mempunyai keluhan kesehatan tinggi yaitu Kendal, Purworejo, Banyumas, Grobogan, Kota Pekalongan, dan Brebes.

Baduta yang pernah mendapatkan ASI lebih sehat daripada yang tidak pernah mendapatkan ASI. Sementara untuk baduta yang berstatus imunisasi tidak lengkap lebih rendah status kesehatannya dibandingkan baduta yang status imunisasinya lengkap atau belum lengkap. Secara bersama-sama, status pemberian ASI dan status kelengkapan imunisasi baduta berpengaruh signifikan terhadap status kesehatan baduta. Hasil penelitian kami harus disikapi dengan baik mengingat data Susenas adalah data sampel dan merupakan data cross sectional. Mengingat rancangan Susenas berbeda dengan rancangan penelitian kami, maka variabel-variabel dalam penelitian ini terbatas pada data yang tersedia. Sebagai contoh, untuk status kesehatan dicerminkan oleh keluhan kesehatan yang dialami selama sebulan yang lalu.

\section{Daftar pustaka}

1. Bank Dunia. Berinvestasi dalam Sektor Kesehatan Indonesia : Tantangan dan Peluang untuk Pengeluaran Publik di Masa Depan. Kajian Pengeluaran Publik Indonesia untuk Sektor Kesehatan 2008. Jakarta: Bank Dunia; 2008.

2. Bappenas. Buku I Ringkasan Eksekutif. Program Nasional Bagi Anak Indonesia (PNBAI) 2015. Jakarta: Bappenas; 2004.

3. BPS. Survei Sosial Ekonomi Nasional. Pedoman Kor. Buku III. Jakarta: 2007.

4. BPS. Survei Sosial Ekonomi Nasional. Pedoman Kepala BPS Provinsi dan Kabupaten/Kota. Buku I. Jakarta: 2007.
5. BPS, BKKBN, Depkes, dan Macro International. Survei Demografi dan Kesehatan Indonesia 1991. Jakarta: 1992.

6. BPS, BKKBN, Depkes dan Macro International. Survei Demografi dan Kesehatan Indonesia 2002-2003. Jakarta: 2004.

7. BPS, BKKBN, Depkes dan Macro International. Survei Demografi dan Kesehatan Indonesia 2007. Jakarta: 2008.

8. BPS dan Depkes. Riset Kesehatan Dasar (Riskesdas) 2007. Jakarta: BPS dan Depkes; 2008.

9. BPS dan Depkes. Riset Kesehatan Dasar (Riskesdas) 2010. Jakarta: BPS dan Depkes; 2010.

10. BPS Provinsi Jawa Tengah. Provinsi Jawa Tengah Dalam Angka tahun 2008. Semarang: BPS Provinsi Jawa Tengah; 2007.

11. Blum, Hendrik. L. Planning for Health. New York: Human Sciences Press; 1984.

12. Collin, T. Health Policy Analysis: a Simple Tool for Policy Makers. Health Public 2005; 119: 192-6.

13. Dinas Kesehatan Propinsi Jawa Tengah. Profil kesehatan Provinsi Jawa Tengah tahun 2005. Semarang: 2005.

14. Goehman, S David. Health Behaviour. Emerging Reserach Persepective. New York: Plenum Press; 1988.

15. Goehman, S David. Hand Book of Health Behaviour. Editor. Goehman, S David. New York: Plenum Press;1997.

16. Mbagaya, Grace M, Mark O Odhiambo, and Ruth K Oniang'o. Mother's health seeking behaviour during child illness in a rural western Kenya community. Afr Health Sci 2005;5:322-7.

17. Mechanic, David. The Influence of Mother on Their Children Health Attitudes and Behavior. Pediatric 1964;33: 444-53.

18. Moallemi, Saied Z, Murtomaa H, Tehranchi A, Virtanen JI. Oral health behaviour of Iranian mothers and their 9-year-old children. Iran: 2007.

19. Moallemi, Saied Z, Murtomaa H, Tehranchi A, Virtanen JI. Influence of mothers' oral health knowledge and attitudes on their children's dental health. Iran: 2007.

20. Nasution, Siti K. Meningkatkan status kesehatan melalui pendidikan kesehatan dan penerapan pola hidup sehat. Jakarta: 2004.

21. North Carolina Department of Health and Human Services. Action for Children, Child Health Report Card. North Carolina Insitude Med; 2006.

22. Rustihauser I, Tienboon P,. Wahlqvist M+IQ. Dietary guidelines for children and adolescents in Australia incorporating the infant feeding guidelines for health workers endorsed 10 April 2003. National Health and Medicine Research Council. 2003. 
23. Seda, Sheila. Breastfeeding : key to child health. Nursing J India. August 2008.

24. Sumargono. Faktor-faktor resiko yang mempengaruhi terjadinya ISPA pada balita di Kelurahan Kelapa Dua Wetan Kecamatan Pasar Rebo Timur. Jakarta: Tesis; 1989.

25. UNICEF, WHO, IDAI. Rekomendasi tentang pemberian makan bayi pada situasi darurat. 2005.
26. Untoro, Rachmi. Balita antara masa emas dan kritis. Dalam: Kesehatan Reproduksi.Com - menyebarluaskan informasi mengenai kesehatan reproduksi dan seksualitas. Jakarta: Agustus 2005.

27. World Vision Indonesia. Dukung perubahan perilaku menuju kesehatan ibu dan anak ke arah yang lebih baik. Jakarta: World Vision Indonesia; 2010. 


\section{Lampiran}

Tabel. Keluhan Kesehatan Baduta dan Rankingnya menurut Kabupaten/Kota di Provinsi Jawa Tengah, Susenas 2007

\begin{tabular}{|c|c|c|c|c|c|c|c|c|}
\hline & \multirow{2}{*}{ Kabupaten/ Kota } & \multicolumn{2}{|c|}{ Ada keluhan } & \multicolumn{2}{|c|}{ Tidak ada keluhan } & \multicolumn{2}{|c|}{ Jumlah } & \multirow{2}{*}{ Ranking } \\
\hline & & $\mathrm{n}$ & $\%$ & $\mathrm{n}$ & $\%$ & $\mathrm{n}$ & $\%$ & \\
\hline 12 & Kab. Wonogiri & 28 & 21,31 & 48 & 78,69 & 61 & 100,00 & 1 \\
\hline 14 & Kab. Sragen & 51 & 27,27 & 48 & 72,73 & 66 & 100,00 & 2 \\
\hline 30 & Kota Magelang & 35 & 29,82 & 40 & 70,18 & 57 & 100,00 & 3 \\
\hline 8 & Kab. Magelang & 31 & 31,75 & 43 & 68,25 & 63 & 100,00 & 4 \\
\hline 1 & Kab. Cilacap & 36 & 33,33 & 56 & 66,67 & 84 & 100,00 & 5 \\
\hline 9 & Kab. Boyolali & 29 & 33,33 & 54 & 66,67 & 81 & 100,00 & 6 \\
\hline 27 & Kab. Pemalang & 30 & 33,33 & 68 & 66,67 & 102 & 100,00 & 7 \\
\hline 11 & Kab. Sukoharjo & 20 & 33,75 & 53 & 66,25 & 80 & 100,00 & 8 \\
\hline 10 & Kab. Klaten & 27 & 33,77 & 51 & 66,23 & 77 & 100,00 & 9 \\
\hline 4 & Kab. Banjarnegara & 26 & 34,44 & 59 & 65,56 & 90 & 100,00 & 10 \\
\hline 16 & Kab. Blora & 27 & 37,14 & 44 & 62,86 & 70 & 100,00 & 11 \\
\hline 3 & Kab. Purbalingga & 13 & 37,63 & 58 & 62,37 & 93 & 100,00 & 12 \\
\hline 7 & Kab. Wonosobo & 38 & 37,97 & 49 & 62,03 & 79 & 100,00 & 13 \\
\hline 21 & Kab. Demak & 18 & 38,36 & 45 & 61,64 & 73 & 100,00 & 14 \\
\hline 33 & Kota Semarang & 46 & 39,73 & 44 & 60,27 & 73 & 100,00 & 15 \\
\hline 20 & Kab. Jepara & 26 & 40,00 & 60 & 60,00 & 100 & 100,00 & 16 \\
\hline 19 & Kab. Kudus & 33 & 40,24 & 49 & 59,76 & 82 & 100,00 & 17 \\
\hline 31 & Kota Surakarta & 40 & 41,79 & 39 & 58,21 & 67 & 100,00 & 18 \\
\hline 5 & Kab. Kebumen & 33 & 41,86 & 50 & 58,14 & 86 & 100,00 & 19 \\
\hline 35 & Kota Tegal & 40 & 42,17 & 48 & 57,83 & 83 & 100,00 & 20 \\
\hline 26 & Kab. Pekalongan & 28 & 42,28 & 71 & 57,72 & 123 & 100,00 & 21 \\
\hline 18 & Kab. Pati & 41 & 43,01 & 53 & 56,99 & 93 & 100,00 & 22 \\
\hline 28 & Kab. Tegal & 32 & 45,79 & 58 & 54,21 & 107 & 100,00 & 23 \\
\hline 32 & Kota Salatiga & 37 & 46,67 & 32 & 53,33 & 60 & 100,00 & 24 \\
\hline 23 & Kab. Temanggung & 50 & 47,76 & 35 & 52,24 & 67 & 100,00 & 25 \\
\hline 22 & Kab. Semarang & 52 & 48,24 & 44 & 51,76 & 85 & 100,00 & 26 \\
\hline 17 & Kab. Rembang & 34 & 48,53 & 35 & 51,47 & 68 & 100,00 & 27 \\
\hline 25 & Kab. Batang & 49 & 48,54 & 53 & 51,46 & 103 & 100,00 & 28 \\
\hline 13 & Kab. Karanganyar & 81 & 48,72 & 40 & 51,28 & 78 & 100,00 & 29 \\
\hline 24 & Kab. Kendal & 17 & 51,39 & 35 & 48,61 & 72 & 100,00 & 30 \\
\hline 6 & Kab. Purworejo & 28 & 51,79 & 27 & 48,21 & 56 & 100,00 & 31 \\
\hline 2 & Kab. Banyumas & 28 & 52,04 & 47 & 47,96 & 98 & 100,00 & 32 \\
\hline 15 & Kab. Grobogan & 29 & 52,87 & 41 & 47,13 & 87 & 100,00 & 33 \\
\hline 34 & Kota Pekalongan & 44 & 64,71 & 24 & 35,29 & 68 & 100,00 & 34 \\
\hline 29 & Kab. Brebes & 35 & 66,39 & 41 & 33,61 & 122 & 100,00 & 35 \\
\hline & Total & 1.212 & 42,47 & 1.642 & 57,53 & 2.854 & 100,00 & \\
\hline
\end{tabular}

